\title{
Studies on sustainable land use and soil ecosystems in tropical peat land
}

\author{
Koyo YonebaYashi \\ Faculty of Agriculture, Kyoto Prefectural University, Sakyo, Kyoto, 606-8522, Japan \\ Present Address: Faculty of Bioresources and Environmental Sciences, Ishikawa Prefectural University, Nonoichi, Ishikawa, 921-8836, \\ Japan \\ E-mail: ky-yone@ishikawa-pu.ac.jp
}

\begin{abstract}
Most tropical peat soil is classified as Oligotrophic peat due to their low N, P, K, and Ca content. The macro- and micro-nutrient status of tropical peat soils in natural forests and under cultivation was studied in Malay peninsular and Sarawak.

The average concentrations of $\mathrm{P}, \mathrm{K}, \mathrm{Ca}$, $\mathrm{Mg}$, and $\mathrm{Fe}$ of tropical peat were significantly lower than those of grass peat in Japan. The $\mathrm{P}, \mathrm{K}, \mathrm{Ca}, \mathrm{Fe}, \mathrm{Mn}$, and $\mathrm{Zn}$ concentrations of surface soils were higher than those of subsoils. Average concentrations of $\mathrm{Ca}$, $\mathrm{Mg}$, and $\mathrm{Fe}$ in Sarawak soils were lower than those of Malay peninsular soils for both surface and subsoils.
\end{abstract}

Based on the analysis of the distribution of the metal forms, most $\mathrm{Cu}$ and $\mathrm{Fe}$ occurred in strongly chelated and nonextractable forms (non-available form). The concentrations of water soluble and exchangeable forms (available form) of Mn, $\mathrm{Zn}$, and $\mathrm{Cu}$ were very low. In the case of fertilized soil, heavy metal content of the surface soils were about 3 to 15 times as high as those of the subsoil. Most of this was accounted for by the weakly chelated, strongly chelated, or non-extractable forms, because the $\mathrm{pH}$ of the surface soil was higher than that of the subsoil. As the chelating effect of humic substances is likely to be pronounced for high soil $\mathrm{pH}$, heavy metals applied in fertilizers were changed into nonavailable forms.

The concentrations of $\mathbf{N}$ and $P$ were fairly high in the soil solution in tropical peat profile, except for $P$ in the profile near the center of the peat dome in a climax forest. Dissolved $P$ consisted mostly of orthophosphate, whereas a large part of $\mathrm{N}$ was in organic forms. $\mathrm{K}$ concentration was not low in the soil solution in the forest as compared with the global average of river water. Low $K$ in soil solution profile was observed at the Sago plantation field in deep peat. Forest clear-cutting disturbs the $K$ cycling in an ecosystem. The concentrations of $\mathrm{Ca}, \mathrm{Mg}$, and Fe were fairly low in the soil solution of peat profile as compared with the average of river water in Japan.

The potential capacity to supply $\mathrm{K}$, Ca, and $P$ was not necessarily high, in spite of the apparent high level observed for the soil solution composition. Therefore, from the viewpoint of nutrient dynamics, the potential for using reclaimed peat land is rather limited, especially under low input management.

Key words: tropical peat, macro- and micronutrient, chelated form, sustainable land use.

\section{INTRODUCTION}

The total area of tropical peat swamp forests, tropical peat lands, in the world amounts to about 30 million ha, two thirds of which are in Southeast Asia. There are about 1.66 million and 0.85 million ha of peat lands in Sarawak, Malaysia and the Malay peninsula, respectively. Peat land is gaining importance as potential land for agriculture, because it is near coastal lowlands, which are usually developed and populated. In recent years, extensive utilization of peat swamp areas has started due to the increasing pressure on upland areas.

Peat soil is generally very acid and deficient in nutrients, particularly $\mathrm{Cu}, \mathrm{Zn}, \mathrm{Fe}$, and $\mathrm{B}$. Under natural conditions, it is flooded and requires drainage before crop cultivation. However, uncontrolled and excessive drainage of peat may result in subsidence and irreversible 
shrinkage of the peat. Wetland rice is the most suitable crop for cultivation in undrained peat soils, taking into account the flat topography and hydrology of peat land and the ability of rice to grow under anaerobic conditions (Driessen \& Permadhysudewo, 1977). Zinc deficiency is the most important micro-nutritional disorder limiting the growth of rice on peat soils (Quijano \& Neue, 1986). In Malaysia, traditionally rubber, pineapples, and annual crops like cassava and vegetables have been cultivated on peat land. Low yields were usually obtained due to poor root penetration and low availability of nutrients. Sago palm, however, is a crop which has been proven to grow successfully on deep peat. Sago palm appears to be capable of adapting itself to the nutritionally poor medium of the deep peat with minimal drainage, because it has very dense and effective root systems.

In this paper, I attempted to analyze the characteristics of the macro- and micro-nutrient status of tropical peat soils in natural swamp forests and under cultivation.

\section{STUDY SITE AND METHODS}

The study areas were at Johor in peninsular Malaysia, Narathiwat in southern Thailand, and Sibu in Sarawak, Malaysia, as shown in Fig. 1. Peat soils were sampled from the coastal swamp forest in natural forest, secondary forest, and crop fields with several reclamation ages as listed in Table 1 . All soils were sampled from $80 \mathrm{~cm}$ depth every $20 \mathrm{~cm}$. Peat soil solution was sampled at Naman Forest Reserve, Sibu and at Sg. Talau Peat Research Station, Mukah, Sarawak, as listed in Table 2. The soil solution was sampled monthly from November 1993 until October 1994, except from January to May. It was collected from a depth of 30 and $80 \mathrm{~cm}$ using a buried PVP pipe.
Iron, manganese, zinc, copper, calcium, magnesium, sodium, and potassium concentrations were analyzed by atomic adsorption spectroscopy after digestion by dry combustion. Phosphorous concentration was determined by colorimetry with molybdenum blue after digestion with nitric and sulfuric acid.

Comparative digestion of $\mathrm{Fe}, \mathrm{Mn}, \mathrm{Zn}$, and $\mathrm{Cu}$ in peat soils were determined by seven sequential extractions of soils according to the method of Mathur \& Levesque (1983). The water soluble metals were extracted with deionized water and the exchangeable form of the metal were extracted with aqueous $\mathrm{CaCl}_{2}$ at $\mathrm{pH}$ 5.0. The metals in or associated with oxides were extracted with aqueous $\mathrm{CaCl}_{2}+$ hydroquinone and metals strongly bound to metals or weakly bound to organic substances were extracted with aqueous acetic acid. The metals specifically sorbed on organic sites were removed by DTPA-TEA (pH 7.3). Additionally, metals in or associated with carbonates or ligand of similar strength were extracted with $\mathrm{HCl}$, and those held as strongly as in sulfides were fractionated with $\mathrm{HNO}_{3}$.

As for the soil solution analysis, total $\mathrm{N}$ content was determined photometrically at $220 \mathrm{~nm}$ after potassium peroxodisulfate oxidation treatment, whereas the contents of $\mathrm{NH}_{4}-\mathrm{N}$ and $\mathrm{NO}_{3}-\mathrm{N}$ were measured with a $\mathrm{N}$ meter (Central Kagaku Co., HC-707N) after steam distillation with successive addition of $\mathrm{MgO}$ and Devarda's alloy. Total and ortho-P contents were determined by molybdenum blue method with or without pretreatment with potassium peroxodisulfate. Contents of $\mathrm{Cl}$ and $\mathrm{SO}_{4}$ were determined by high performance liquid chromatography on an ODS column using 0.8 $\mathrm{mM}$ trimesic acid and $1.0 \mathrm{mM}$ tetra- $n$-butylammonium hydroxide solution in water at $\mathrm{pH} 4.6$ as a mobile phase. Fe content was measured by inductively plasma atomic emission spectrometry (Seiko, SPS 1500).

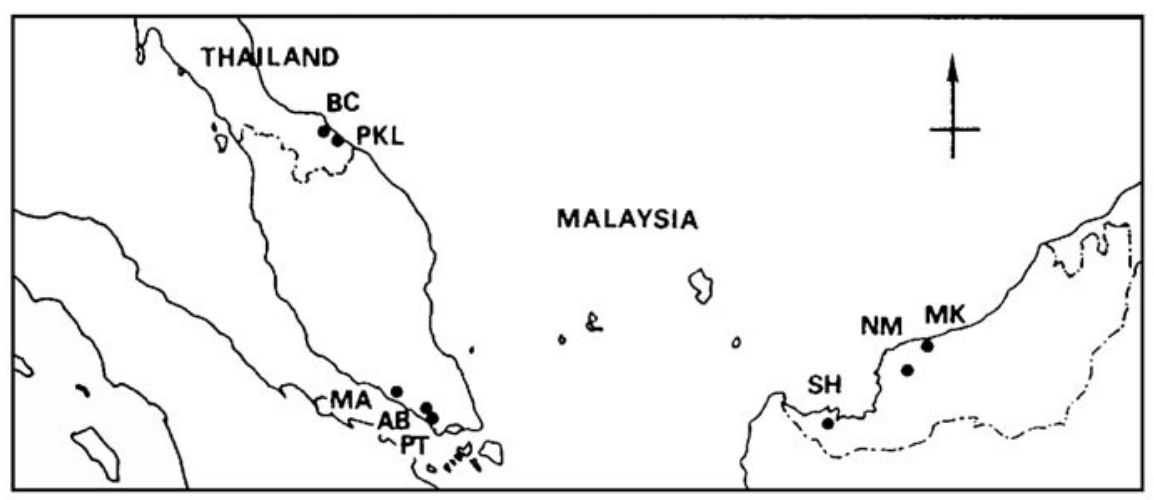

Fig. 1. Map showing the study areas 
Table 1. Study sites for chemical analysis of peat profiles

\begin{tabular}{lll}
\hline AB-1 & Ayer Baloi, Johor, Malaysia & natural forest \\
AB-2 & Ayer Baloi, Johor, Malaysia & 1st year of reclamation \\
MAT & Muar, Johor, Malaysia & natural forest \\
PN-1 & Pontian, Johor, Malaysia & MARDI stations field \\
BC-2 & Bacho, Narathiwat, Thailand & grass, fern \\
BC-10 & Bacho, Narathiwat, Thailand & secondary forest \\
KDT & Kab Dean, Narathiwat, Thailand & secondary forest \\
NM-1 & Naman, Sibu, Sarawak & secondary forest \\
NM-2 & Naman, Sibu, Sarawak & secondary forest \\
NM-3 & Naman, Sibu, Sarawak & natural forest \\
SA-1 & Samarahan, Sarawak & natural forest \\
SB-1 & Sungai Biddut, Sarawak & farmers field \\
\hline
\end{tabular}

composition of the surface soils was different from that of subsoils, in which the chemical content every $20 \mathrm{~cm}$ layers was homogeneous. The mean concentrations of macro- and micronutrients in the surface and subsoils of Sarawak and Malay peninsular are shown in Fig. 2 and 3, excluding the $\mathrm{PN}-1$ soil that showed extremely high $\mathrm{Ca}$ and $\mathrm{Cu}$ concentrations with fertilization. The average concentrations of $\mathrm{P}, \mathrm{K}, \mathrm{Ca}, \mathrm{Mg}$, and Fe ranged from 0.3 to $0.7 \mathrm{mg} \mathrm{g}^{-1}, 0.1$ to $0.3 \mathrm{mg} \mathrm{g}^{-1}$, 0.4 to $1.3 \mathrm{mg} \mathrm{g}^{-1}, 0.3$ to $0.9 \mathrm{mg} \mathrm{g}^{-1}$, and 0.8 to 1.9 $\mathrm{mg} \mathrm{g}^{-1}$, respectively. These concentrations were completely lower than that of grass peat in Japan, except for the $\mathrm{P}$ concentrations of surface soils. The mean concentrations of $\mathrm{Mn}, \mathrm{Zn}$, and $\mathrm{Cu}$ were from 5 to $9 \mathrm{mg} \mathrm{kg}^{-1}, 4$ to $7 \mathrm{mg} \mathrm{kg}^{-1}$, and 4 to

Table 2. Study sites for chemical analysis of soil solution in peat profile

\begin{tabular}{lll}
\hline N-1 & Naman, Sibu, Sarawak & secondary forest \\
N-4 & Naman, Sibu, Sarawak & natural forest (Alan forest) \\
T-2 & Talau, Mukah, Sarawak & Sago palm plantation \\
T-3 & Talau, Mukah, Sarawak & secondary forest \\
\hline
\end{tabular}

\section{CHEMICAL COMPOSITION AND DISTRIBUTION OF HEAVY METALS AMONG DIFFERENT BONDING FORMS IN TROPICAL PEAT SOILS}

Tropical peat used in this study were very acidic, with $\mathrm{pH}$ from 3.1 to 4.6 for surface soils 0 to $20 \mathrm{~cm}$ depth, and from 3.0 to 4.2 for subsoils 20 to $80 \mathrm{~cm}$ depth. The chemical
$7 \mathrm{mg} \mathrm{kg}^{-1}$, respectively. According to the definition given by Fleisher (Driessen \& Soepraptohardjo, 1974), the peat soils sampled were classified as Oligotrophic peat soils. The P, K, Ca, Fe, Mn, and $\mathrm{Zn}$ concentrations of surface soils were higher than those of subsoils in both regions. These results agreed with those reported in a previous study (Driessen, 1987). The Ca, Mg, and Fe contents of Sarawak soils were lower than that of Malay peninsular soils, though the P content of the Sarawak soil was higher than that of the Malay soil.

The analysis of the distribution of heavy metals is summarized in Fig. 4 and 5. Zn occurred in all forms, namely water soluble, calcium exchangeable, oxides, weakly chelated, strongly chelated, carbonates, sulfides, and non-extractable forms. About $31 \%$ of the total amount

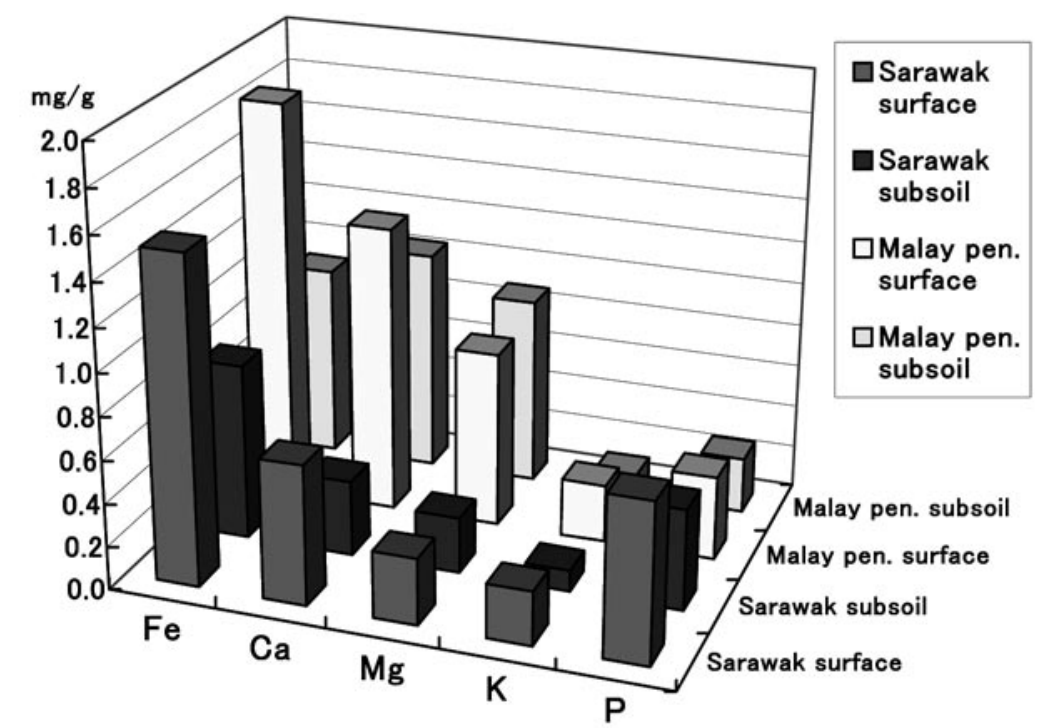

Fig. 2. Total $\mathrm{P}, \mathrm{K}, \mathrm{Ca}, \mathrm{Mg}$, and Fe concentrations in surface and sub-layers of peat soils in Sarawak and Malay peninsular 


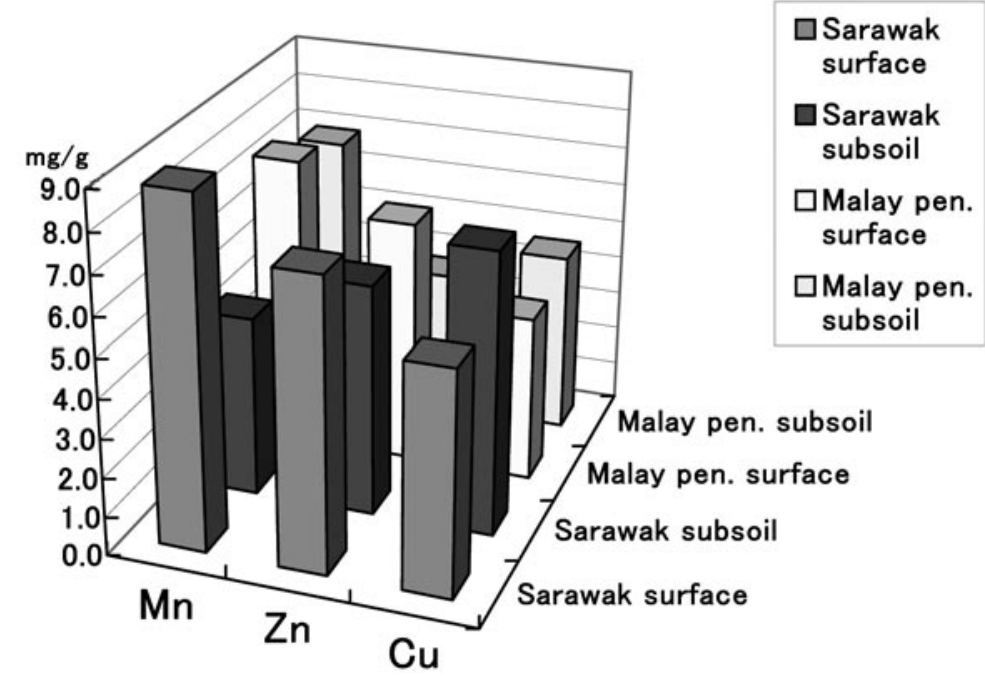

Fig. 3. Total $\mathrm{Cu}, \mathrm{Zn}$, and $\mathrm{Mn}$ concentrations in surface and sub-layers of peat soil in Sarawak and Malay peninsular
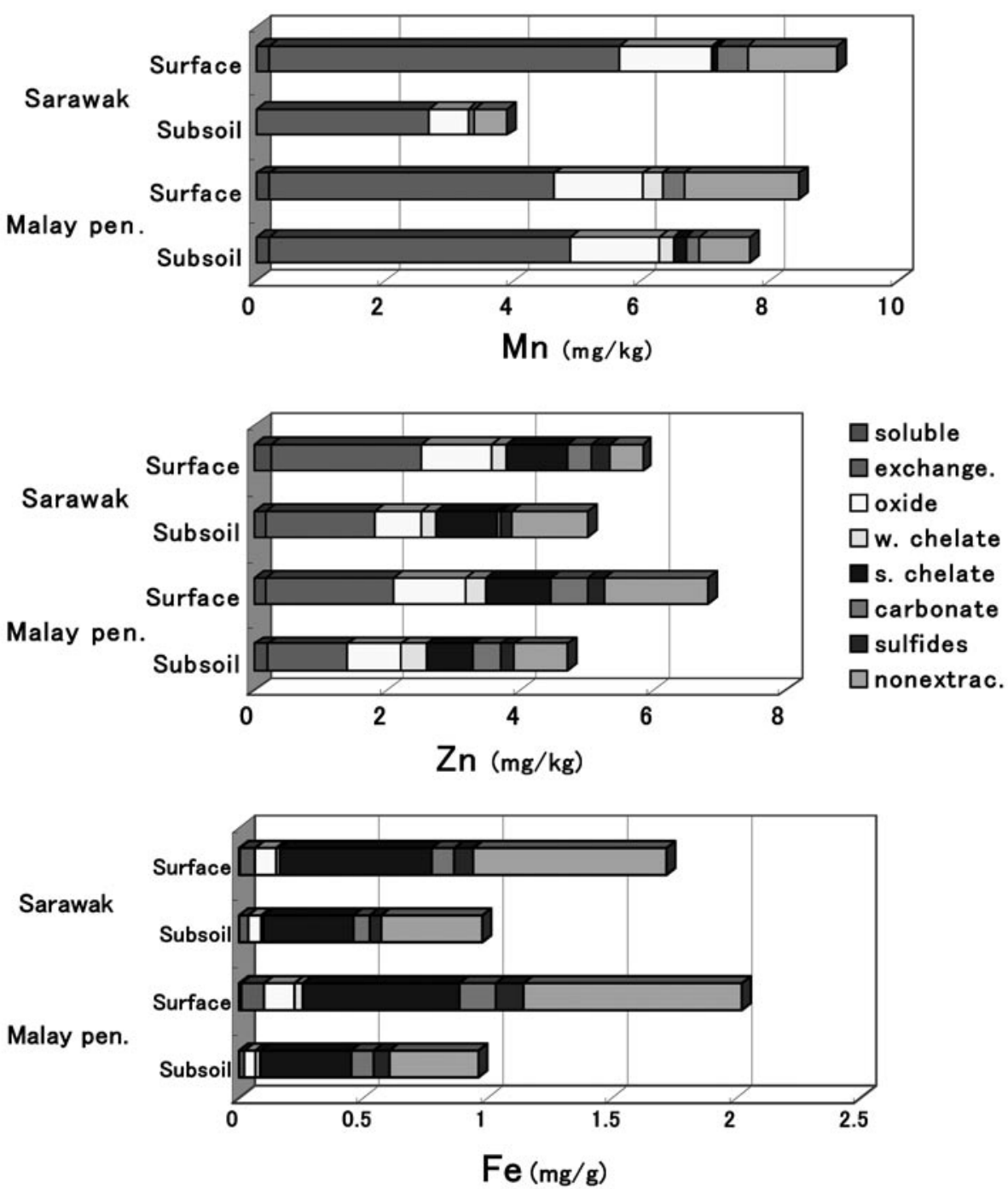

Fig. 4. Distribution of $\mathrm{Mn}, \mathrm{Zn}$, and $\mathrm{Fe}$ in soils among various sequentially extracted forms, based on $\mathrm{mg} \mathrm{kg}^{-1}$ or $\mathrm{mg} \mathrm{g}^{-1}$ concentrations in soils 


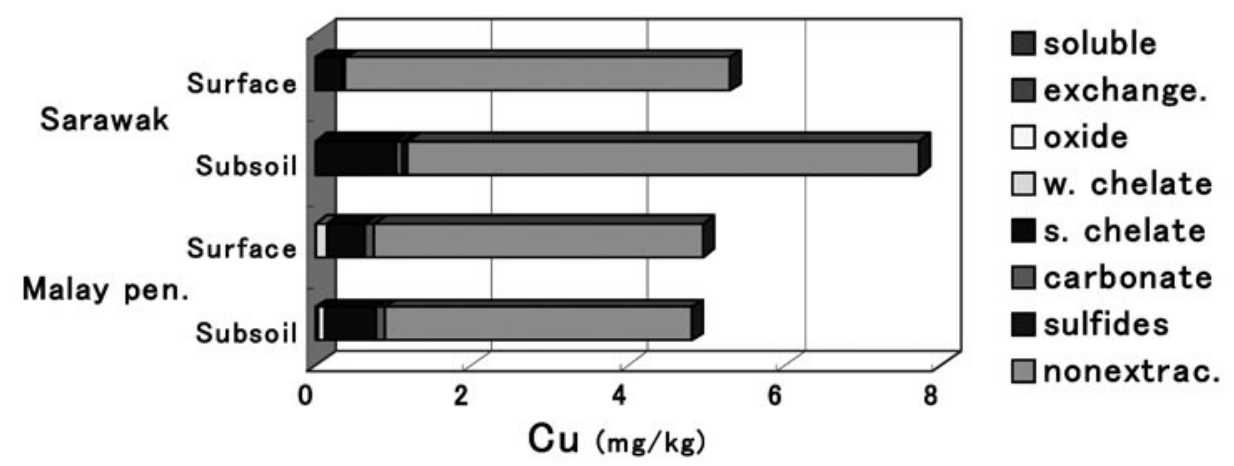

Fig. 5. Distribution of $\mathrm{Cu}$ in soils among various sequentially extracted forms, based on $\mathrm{mg} \mathrm{kg}^{-1}$ concentrations in soils
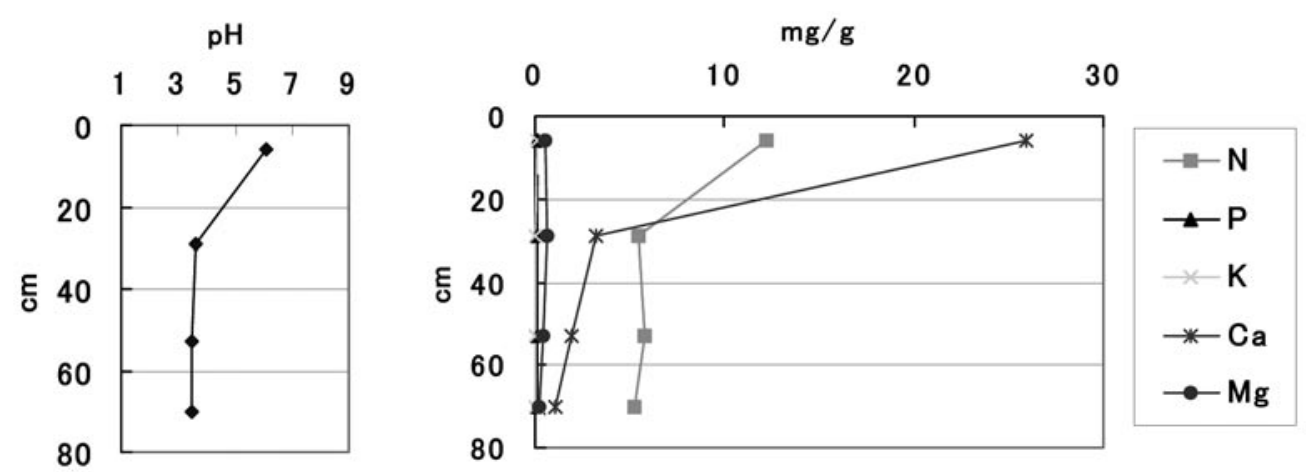

Fig. 6. The $\mathrm{pH}$ and total $\mathrm{N}, \mathrm{P}, \mathrm{K}, \mathrm{Ca}$, and $\mathrm{Mg}$ concentrations in a $\mathrm{PN}-1$ soil profile (Yonebayashi et al., 1994)
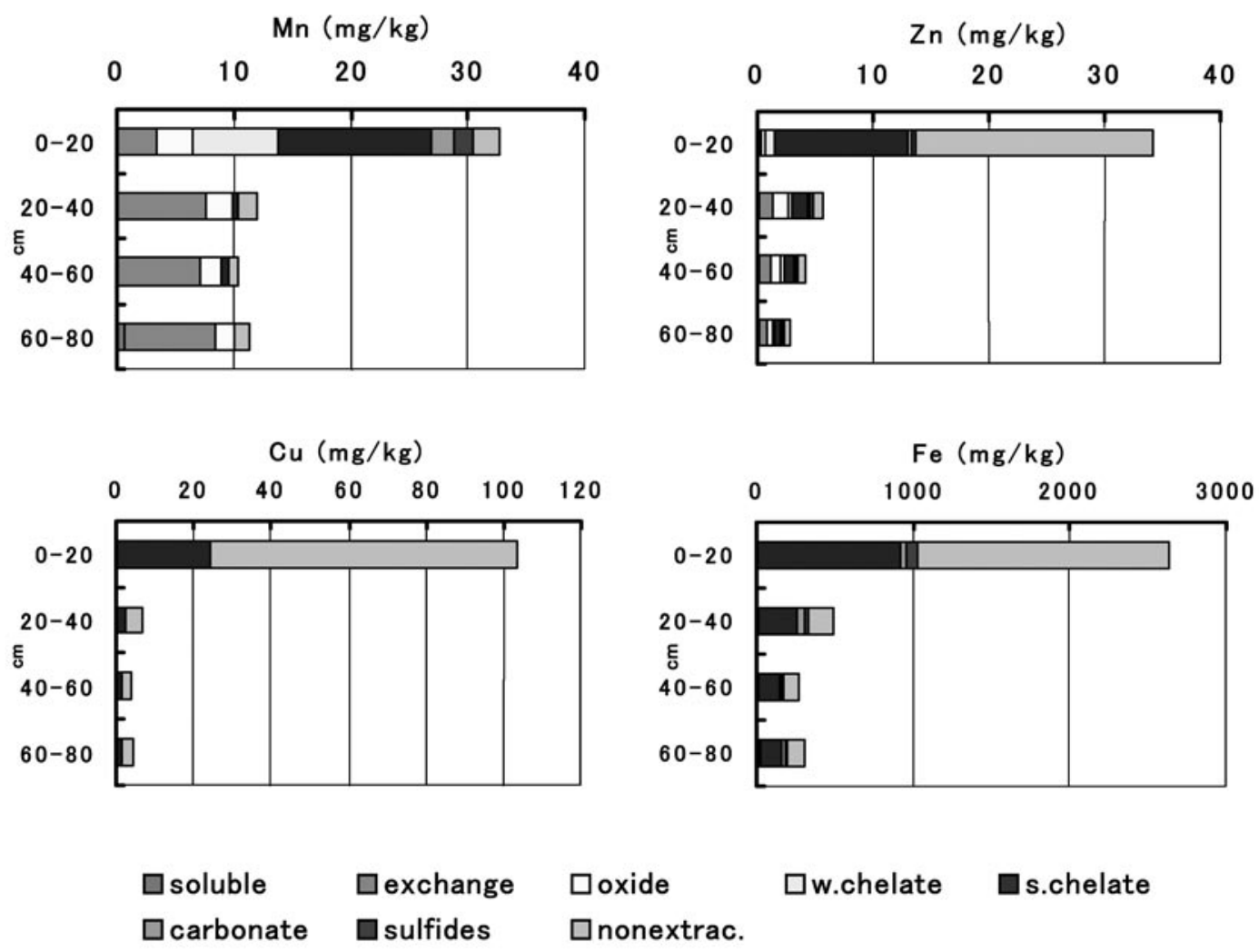

Fig. 7. Distribution of $\mathrm{Mn}, \mathrm{Zn}, \mathrm{Fe}$, and $\mathrm{Cu}$ in $\mathrm{PN}-1$ soil profile among various sequentially extracted forms (Yonebayashi et al., 1994) 
of $\mathrm{Zn}$ in the Malay peninsular soils and 43 and $36 \%$ of $\mathrm{Zn}$ in surface and subsoils in Sarawak, respectively, on average corresponding to about 1 to $2 \mathrm{mg} \mathrm{kg}^{-1}$ for these soils, were in the water soluble and $\mathrm{Ca}$ exchangeable fractions, which is immediately available to plant growth (so-called intensity factor). Most of the Mn was found in the reactive fractions of the water soluble, $\mathrm{Ca}$ exchangeable, and readily reducible (oxides) forms. About 55 and $60 \%$ of the total amount of Mn in the surface soils from Malay peninsular and Sarawak, corresponding to about $4.6 \mathrm{mg} \mathrm{kg}^{-1}$ and $5.7 \mathrm{mg} \mathrm{kg}^{-1}$, respectively, were in available forms (water soluble and Ca exchangeable).

As shown in Fig. 4, Fe was mostly present in nonextractable and strongly chelated forms. Only about 4 and $5 \%$ of the total amount of Fe in the surface soils of Malay peninsular and Sarawak corresponding to about $100 \mathrm{mg}$ $\mathrm{kg}^{-1}$ and $64 \mathrm{mg} \mathrm{kg}^{-1}$, respectively, were in water soluble and $\mathrm{Ca}$ exchangeable forms. Fig. 5 shows that most of the $\mathrm{Cu}$ occurred in non-extractable and strongly chelated forms. Only $1 \%$ of the total $\mathrm{Cu}$ in subsoils of peninsular Malay peat, on the average, corresponding to $0.04 \mathrm{mg}$ $\mathrm{kg}^{-1}$, was in a water soluble form. $\mathrm{Cu}$ of Sarawak soils did not occur in the water soluble and $\mathrm{Ca}$ exchangeable fractions. Therefore, $\mathrm{Cu}$ in the peat soils was hardly available for plant growth.

In the case of PN-1 soils, which were sampled from a field at the MARDI experimental station, the surface soil was nearly neutralized by liming and enriched in $\mathrm{N}$ content, as shown in Fig. 6. The $\mathrm{Cu}$ content of surface soil showed a high value of $104 \mathrm{mg} \mathrm{kg}^{-1}$, though all of the copper occurred in strongly chelated and non-extractable forms. The $\mathrm{pH}$ of the surface soils was 6.1 and that of subsoils ranged from 3.5 to 3.6. Humus-metal complexes are more stable at higher $\mathrm{pH}$ values where the carboxylic groups of humic substances dissociate more readily than at lower $\mathrm{pH}$ values (Stevenson, 1982).

Consequently, $\mathrm{Cu}$ applied in fertilizer changed into a non-available form in nearly neutralized surface soils. The Fe and $\mathrm{Zn}$ concentrations $\left(2.64 \mathrm{~g} \mathrm{~kg}^{-1}\right.$ and 34.3 $\left.\mathrm{mg} \mathrm{kg}{ }^{-1}\right)$ in the surface soil were about 5 to 11 times higher than those in the subsoil, though most Fe and $Z n$ occurred in strongly chelated and non-extractable forms. The Mn content of the surface was about 3 times that of the subsoil. Most is occurred in weakly chelated and strongly chelated forms. These results suggest that micro-elements applied in fertilizers become unavailable in nearly neutralized peat soils. (Yonebayashi et al., 1994)

\section{CHEMICAL COMPOSITION OF PEAT SOIL SOLUTION (Funakawa et al., 1996)}

The $\mathrm{pH}$ of peat soil solution ranged from 4.4 to 4.8 in the upper layer and ranged from 4.7 to 5.7 in the lower layer of peat in study site. The reason why the solution $\mathrm{pH}$ was generally higher than the $\mathrm{pH}$ of the soil suspension was not clear. EC of the soil solution was quite low, ranging from 10 to $50 \mu \mathrm{S} \mathrm{cm}^{-1}$, which may effect the $\mathrm{pH}$ measurement. Fig. 8 and 9 show mean concentration of each element of soil solution. The data for the river water in Japan and in the world presented by Kitano (1992) are also shown for comparison with tropical peat soil solution.

The concentration of $\mathrm{N}$ and $\mathrm{P}$ in the soil solution were fairly high as compared with river water. Dissolved $\mathrm{P}$ in the soil solution consisted mostly of ortho-phosphate, whereas a large part of the $\mathrm{N}$ was in organic form. The $\mathrm{N}$ and $\mathrm{P}$ cycled actively in the plant and peat soil ecosystems. A lower concentration of $\mathrm{P}$ was detected in the soil solution from $\mathrm{N}-4$, which was sampled near the center of the peat dome in a climax forest.

$\mathrm{Ca}, \mathrm{Mg}, \mathrm{Na}, \mathrm{Fe}, \mathrm{Cl}$, and $\mathrm{SO}_{4}$ concentrations in soil solution were lower than those of river water. The concentration of $\mathrm{K}$ in soil solution from both a natural forest and secondary forest was not low as compared with the global average of river water. The $\mathrm{K}$ concentration of the soil solution under the Sago plantation was lower than that of secondary forest near the Sago field. The decrease of $\mathrm{K}$ in soil solution could be attributed to the $\mathrm{K}$ uptake by Sago palms and the $\mathrm{K}$ cycling in the ecosystem in forests disturbed by clear cutting.

The concentrations of $\mathrm{K}, \mathrm{Ca}$, and $\mathrm{P}$ in the soil solution of the upper layer were higher than those of the lower layer for $\mathrm{N}-4$ in a climax forest, which showed that the $\mathrm{K}, \mathrm{Ca}$, and $\mathrm{P}$ were cycled actively in the natural forest and peat soil ecosystems.

\section{INTENSITY FACTOR AND CAPACITY FACTORS FOR DETERMINING THE SUPPLY OF NUTRITIONAL ELEMENTS IN PEAT SOILS (Funakawa et al., 1996)}

Soil solution composition showed that the concentration of $\mathrm{N}, \mathrm{P}$, and $\mathrm{K}$ in the solution were not appreciably low, even in the Oligotrophic peat, except for $\mathrm{P}$ in the very deep peat in a climax forest and for $\mathrm{K}$ in deep peat under Sago cultivation. However, since the concentrations of exchangeable bases and bulk density in the soil solid 


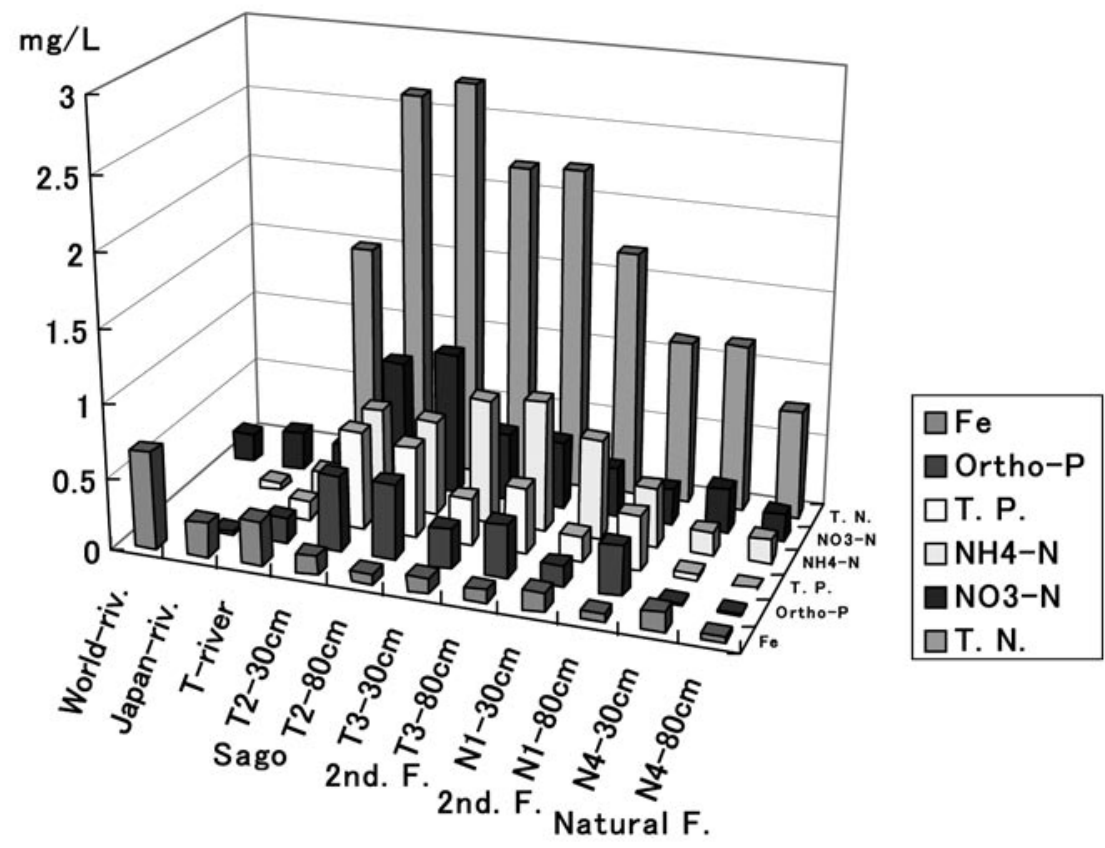

Fig. 8. Average concentration of the soil solution sampled

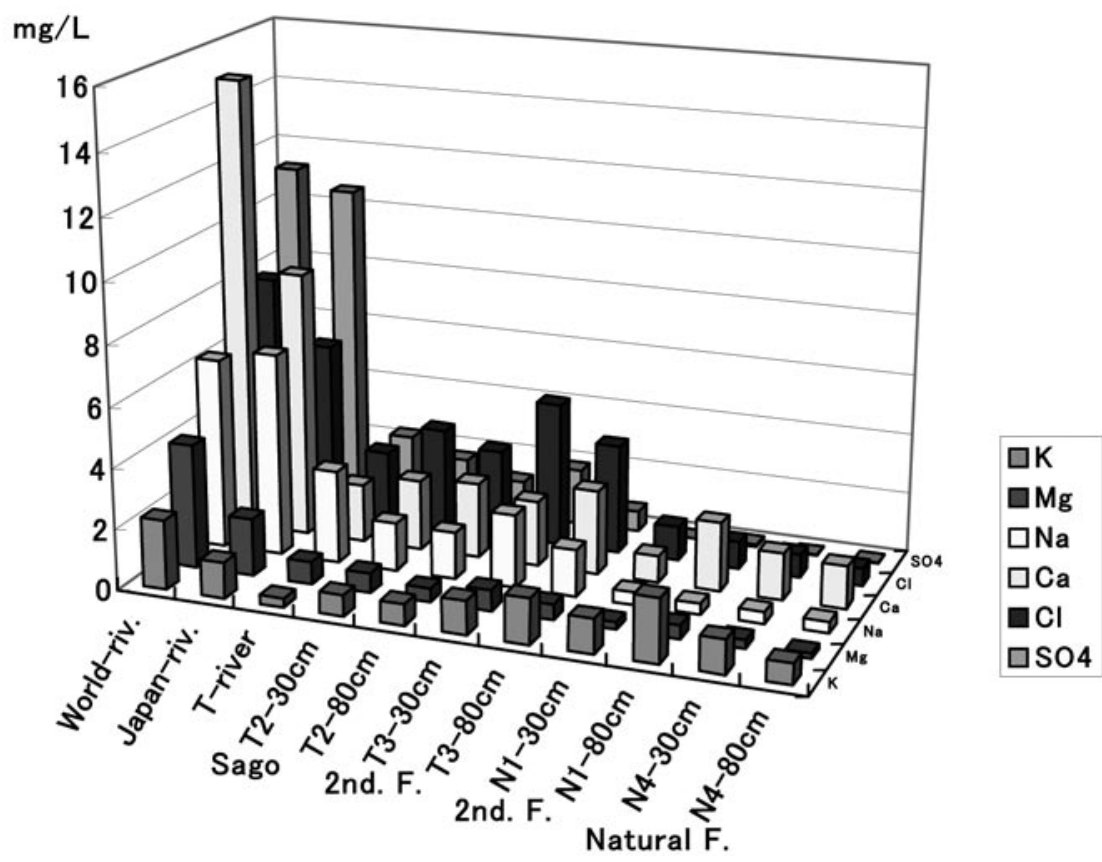

Fig. 9. Average concentration of the soil solution sampled

phase were much lower in the peat soils than in ordinary mineral soils, the capacity of the solid phase to supply nutritional elements was not necessarily high in the peat soils, in spite of the apparent high concentration, or intensity, of these elements in the soil solution. Therefore, once a large part of these nutrients was lost from the solution phase, they may not be easily replenished from the soil solid phase, which may account for the fact that a clear depletion of $\mathrm{K}$ was observed at the soil under Sago cultivation.

The surface accumulation of $\mathrm{K}$ and $\mathrm{Ca}$ observed in the soil solution in the deep peat in a natural forest and the depletion of $\mathrm{K}$ at the forest reclaimed site suggested that significant amounts of these elements were naturally cycled between the peat soils and forest vegetation and, therefore, after reclamation of a forest, a large part of them could be lost from the system within a relatively short period. Thus, from the viewpoint of nutrient 
dynamics, the use of reclaimed peat land is rather limited, especially under low input management.

\section{REFFERNCES}

Driessen, P. M. 1987. Peat Soils. In: Soil and Rice, Pp. 763-779, IRRI, Los Banos.

Driessen, P. M. \& Permadhysudewo. 1977. A review of crops and crop performance of Southeast Asia lowland peats. Soil Research Institute, Bogor, Bulletin 4: 4-7.

Driessen, P. M. \& Soepraptohardjo, M. 1974. Soils for agricultural expansion in Indonesia. Soil Research Institute, Bogor, Bulletin 1: 41-55.

Funakawa, S., Yonebayashi, K., Shoon, J. F. \& Chai, E. O. K. 1996. Nutritional environment of tropical peat soils in Sarawak, Malaysia based on soil solution composition. Soil Science and Plant Nutrition 42: 833-843.

Kitano, Y. 1992. Water Geochemistry. In: Encyclopedia of Earth System Science, Vol. 4, Pp. 449-462, Academic Press, New York.

Mathur, S. P. \& Levesque, M. P. 1983. The effects of using copper for mitigating histosol subsidence on: 2. The distribution of copper, manganese, zinc, and iron in an organic soil, mineral sublayers, and their mixtures in the content of setting a threshold of phytotoxic soil copper. Soil Science 135: 166-176.

Quijano, C. C. \& Neue, H. U. 1986. Zinc deficiency in rice on Philippine peat soils. In: Classification Characterization and Utilization of Peat Land. Proc. 2nd Int. Soil Management Workshop, Pp. 137-150, DLD, Bangkok.

Stevenson, F. J.1982. Stability constants of metal complexes with humic and fulvic acids. In: Humus Chemistry, Pp. 355-373, Weiley, New York.

Yonebayashi, K., Okazaki, M., Pechayapisit, J., Vijarnsorn, P., Zahari, A. B. \& Kyuma, K. 1994. Distribution of heavy metals among different bonding forms in tropical peat soils. Soil Science and Plant Nutrition 40: 425-434.

Received $3^{\text {rd }}$ Mar. 2006

Accepted $20^{\text {th }}$ Mar. 2006 